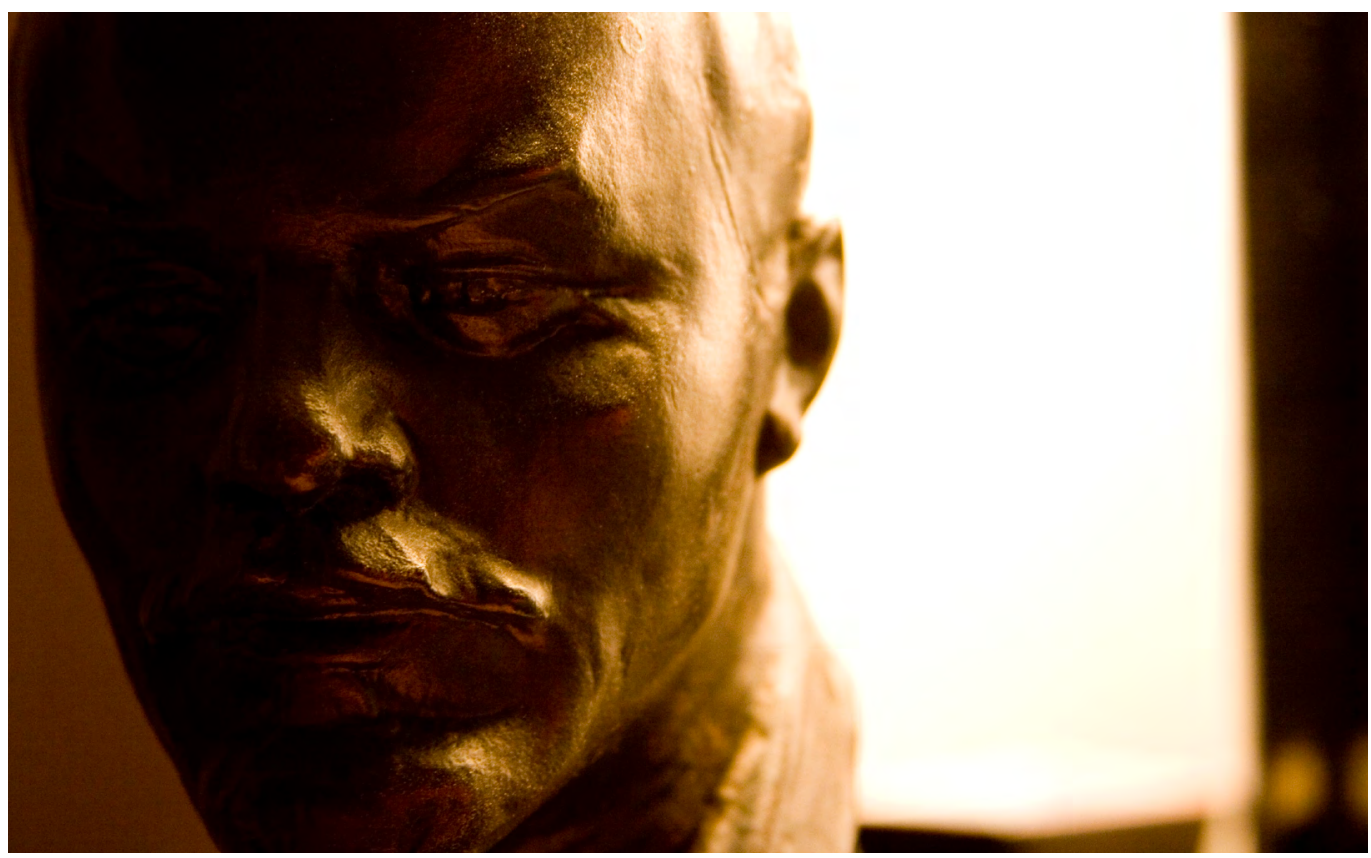

\title{
Leninists in a
}

Lenin. PC: Enrico Sola.

\section{Chinese Factory:}

\section{Reflections on the Jasic Labour Organising Strategy}

\section{ZHANG Yueran}

Led by Maoist activists, in the summer of 2018, a unionisation drive at the Shenzhen Jasic Technology Co. Ltd led to high-profile confrontation with the employer and the state. This essay examines the decade-long labour organising strategy implemented by the Maoist activists behind the struggle. The making of this strategy was a cause for admiration, but its shortcomings hold equally important lessons for China's labour movement in the future.

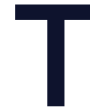

his summer marks the second anniversary of the failed unionisation drive at the Shenzhen Jasic Technology factory, an episode in China's recent history of labour activism that has drawn massive attention from China observers, leftist circles, and media pundits around the world. Compared with other influential instances of contentious labour action in recent years, the Jasic struggle is unique for its militant and combative tactics (including the staging of protests in front of a police station), the prominent role played by young leftist students in solidarity actions, the highly political and Maoist rhetoric, and the unusually harsh and wide-ranging crackdown 
that occurred in its wake. Indeed, in discussing the Jasic struggle, commentators have mostly focussed on these aspects.

However, little attention has been paid to the labour organising strategy underlying the struggle. The labour action at Jasic was by no means spontaneous. Instead, it was the culmination of a quite elaborate and ambitious strategy of labour organising that had been systematically implemented by a group of activists for about a decade before the Jasic struggle broke out. Making clear what this strategy was, and critically reflecting on its achievements and shortcomings, is thus crucial to the charting of future paths of labour organising in China, particularly given the harsh reality labour activists currently face in the country.

The Jasic labour organising strategy has received almost no public attention for two reasons. First, because this strategy was implemented in a rather secretive manner, its existence was not well known at the time when the Jasic struggle gained momentum. Second, in the wake of the severe crackdown, those who had some knowledge of this strategy were reluctant to make it public out of the fear that doing so would politically compromise the detained activists who were involved in the struggle. Partly for these reasons, I opted to not mention this strategy at all in the op-ed I wrote for the Made in China Journal in late 2018, immediately after the large-scale police raid on the Jasic Workers Solidarity Group (佳 士工人声援团).

The situation has changed since then. According to several trusted informants, it is clear that the state has by now accumulated thorough knowledge about this labour organising strategy and dismantled the activist network that had been implementing it. In other words, the main concern that has been giving me pause no longer exists. On the other hand, an open discussion about this strategy is now needed more than ever, since the significantly tightened organising space in the wake of the Jasic struggle has forced labour activists to revisit the question of 'what is to be done' based on a critical reflection of past initiatives.

Drawing on extensive conversations with those who had intimate knowledge of this labour organising strategy, two of whom appeared in an incredibly informative interview (Reignite 2019), as well as with those who had been part of the activist network implementing it, in this essay I offer an overview of this strategy and some preliminary reflections on its accomplishments and the dilemmas those implementing it struggled with.

\section{A Review of the Jasic Struggle}

Before discussing the labour organising strategy leading to the contentious unionisation campaign at Jasic, it might be helpful to give a brief recap of the Jasic struggle itself. In May 2018, several workers at Jasic lodged complaints over a wide range of workplace grievances at the Pingshan district branch office of China's official trade union, the All-China Federation of Trade Unions (ACFTU). While receiving the workers, some local ACFTU officials there suggested unionisation as a possible way to resolve their grievances and informed them of the legal procedure to do so.

In June, a handful of Jasic workers launched a unionisation petition. Within a couple of weeks, about 80 coworkers-roughly 10 percent of the workforce-signed the petition. The employer soon found out about the unionisation drive, and fired the leading worker activists. The fired workers protested outside the factory, during which they were beaten by the police. In response to the violence, they staged protests in front of a local police station, at which point their campaign started to draw wide public attention. As a result, on 27 July a total of 30 individuals, including both Jasic worker activists and their supporters, were detained. 
After the mass detention, dozens of leftist college students and Maoist-leaning activists came to Pingshan to form the Jasic Workers Solidarity Group. In the following month, the group held solidarity actions on a daily basis calling for the release of the detained workers. On 24 August, the police raided the apartment where the solidarity group-whose membership at that point had reached about 50-resided, sending some of the members back home while detaining others.

Subsequent waves of crackdown ensued. About a dozen of the activists who were involved in organising the Jasic struggle and solidarity actions were detained in November 2018. Universities disciplined the students who had joined the Jasic Workers Solidarity Group and severely restricted the activities of the Marxist student associations of which these students were part. Peking University, for example, effectively disbanded its Marxist Studies Society in the name of 'reorganisation' in December 2018. Students who protested these disciplinary actions and restrictions were detained in early 2019; even those who were not formally detained reported experiencing extensive monitoring, harassment, intimidation and physical abuse, as detailed in an account provided by an anonymous Peking University student (Made in China Journal 2019). Later, the scale of the crackdown was also expanded to affect those labour activists who had no personal connections whatsoever with the Jasic struggle, some of whom were detained throughout 2019.

In terms of the number of people detained, the scale of this crackdown was truly unprecedented. More generally, in the wake of the Jasic struggle the Chinese state has adopted an even more hostile stance towards labour activism. As a result, various labour activists and organisations have seen their already limited organising space shrinking even more, leading many to claim that China's labour movement is now at a historic low tide.

\section{The Making of a Labour Organising Strategy}

The Jasic unionisation drive was not an isolated instance of labour activism that 'just happened'. Instead, it represented the climax of a systematic, long-term strategy of labour organising. In the late 2000s, a small group of Maoist activists-some of whom had just graduated from college, whereas others had prior experiences working with antiprivatisation protests by workers in stateowned enterprises-settled in the Pearl River Delta (PRD) and sought to make a systematic intervention in the labour scene there. This strategic decision was informed in part by a political assessment that identified the area as the new frontier of working-class struggles, and also by an optimistic outlook that believed China was on the verge of a breakthrough for leftist politics. If we remember that in the late 2000s Bo Xilai's 'Chongqing Model' greatly increased the political confidence of many Maoist communities in China, workers in state-owned enterprises were still a bastion of militancy, and labour struggles by migrant workers in the PRD were also gaining momentum, it is not difficult to understand where this optimistic outlook came from.

This small group of Maoist activists established close connections with Marxist student associations at several universities that had also adopted a Maoist ideology. Through these student connections, the Maoist activists recruited college graduates to join their ranks. Upon graduation, these students, in turn, would become factory workers and then go on to work themselves as underground labour activists. These recruitment efforts grew over time, and some of the college graduates ended up as core leaders in this Maoist labour activist network in the PRD. The underlying idea was that by abandoning a middle-class career for life-long labour activism, the students would dedicate 
themselves to the revolutionary cause. The experiences of leftist students in the Korean labour movement in the 1980s, particularly as described in Hagen Koo's Korean Workers (2001), were often cited as an inspiration.

These activists usually sought employment in small factories notorious for bad working conditions. They were then expected to agitate their coworkers for some form of collective action as soon as possible, which in some cases resulted in material concessions from the employers. Through this process, the activists were also expected to identify coworkers who were particularly passionate and recruit them to join the activist ranks, while converting these new worker-activists into Maoists along the way. Upon the completion of a collective action, the underground activists would leave the factory and bring with them the newly recruited workers-turned-activists. They would then identify another factory to seek employment in and agitate for collective action there as underground labour activists.

Therefore, this Maoist labour activist network grew by recruiting both college graduates and migrant workers. It was deliberately modelled on a version of the Leninist vanguard party in which the 'petty-bourgeois' intellectuals equipped with revolutionary theory and the most politically 'advanced' elements of the working class combined into an organic whole. In principle, the revolutionary cadre of working-class origins, through political education led by the intellectuals, would become well versed in revolutionary theory (in this specific case, a Maoist politics). Indeed, these activists saw their network as a quasiparty. By gradually increasing the size of this formation and the scale of the collective actions they agitated for, the activists hoped that their network would eventually play a leading role in the burgeoning labour movement in the PRD and guide it towards a revolutionary politics. At the same time, some activists in the network were sent to work in the official trade union or set up community-based NGOs in order to assist the overall organising project as needed.
This strategy met with mixed results. On the one hand, many college graduates were unprepared for life as a worker and underground activist. The physical toll of the gruelling work on the shopfloor was in and of itself overwhelming, leaving little space and energy for organising. Before entering factories, many of them had also been under the illusion that since they were equipped with the 'correct' theory, migrant workers would naturally follow their lead. Very often, this illusion was quickly shattered on the shopfloor. In particular, the Maoist vocabulary-the only vocabulary many student activists knew how to use-failed to connect with rank-and-file workers. Lost, exhausted, and not knowing what to do, many decided to quit. Therefore, even though this Maoist network became ever more successful in recruiting college graduates, the attrition rate was also high.

On the other hand, over the years some activists in the network did successfully organise a few collective actions in the factories they worked in and recruited coworkers to join the ranks of revolutionary activists. Compared with many labour NGOs in the PRD that focussed on 'assisting' or 'advising' workers trying to organise collective actions, the Maoist underground activists, as workers, did not hesitate to lead the fight themselves, personally taking on great political risks. The audacity and sincerity embodied in 'leading by example' enabled some of these activists to win coworkers' trust and recruit a few of those coworkers to become revolutionary cadres. Over more than a decade, this Maoist activist network was able to gain several dozen members.

Around 2015, the growth of this network reached a plateau and stagnated. A sense of demoralisation started to spread among its ranks, which, coupled with the increased hostility from the state towards labour activism, posed nothing short of an existential threat to the endeavour. It was in this context that the leaders of the network found it necessary to agitate for a much more influential collective 
action in a larger factory, in order to both reenergise the demoralised cadres and boost confidence in this organising model. He Pengchao, a graduate of Peking University who became one of the most important leaders in this network, said in a confession video that after surveying several options, the network decided to send underground activists to Jasic in 2016 and started to plan for a largescale confrontational collective action (Jasic Worker Support Group 2019). I have been able to independently verify He's account through other informants.

All of the workers leading the unionisation drive at Jasic in 2018 were in fact underground activists sent in by the Maoist network to agitate, and almost no other Jasic workers participated in the protests organised by the activists. That these activists were able to convince 80 co-workers to sign the unionisation petition within a couple of weeks was a very impressive achievement, but this support base was still not strong enough to anchor a vibrant unionisation campaign and withstand harsh suppression from the employer and the state alike. Unfortunately, the campaign was met with severe and swift repression when the underground worker-activists still lacked widespread and robust support among coworkers. Overall, the engagement from coworkers was limited throughout. This weakness became debilitating after the leading worker-activists were detained on 27 July 2018-at that time, no Jasic workers stepped up to become new workplace leaders to carry the campaign forward, nor did Jasic workers themselves attempt to organise protests or industrial actions in solidarity with the detained activists.

Instead, with the formation of the studentled Jasic Worker Solidarity Group, the centre of action and attention quickly shifted to leftist students. Because of the close connections between the Maoist activist network in the PRD and the Marxist student associations at various universities, leftist students were rapidly mobilised to join the solidarity group en masse. Indeed, the Maoist activist network used this occasion more or less as an educational opportunity to agitate these college students and amplify its call on them to become factory workers and dedicate themselves to the political cause upon graduation.

\section{An Extraordinary Feat}

Despite the tragic ending of the Jasic struggle, the very fact that this sophisticated and multi-layered labour organising strategy had been devised and implemented over more than a decade is in itself an extraordinary accomplishment. For one, this strategy required of its participants-those of both intellectual and working-class origins-an extremely high level of commitment. The fact that several dozen individuals dedicated themselves to such a strategy is a cause for great respect for China's young generation of leftists.

There has been a near-consensus among China's labour activists that the Chinese labour movement has been both fragmented and sporadic. Labour unrest has broken out every now and then in Chinese factories, but it has been hard to imagine how to channel it into some sort of enduring organising project. For Chinese labour activists, therefore, it has been extremely difficult not to feel buried in case-by-case organising, to not lose sight of the forest for the trees, or to formulate any kind of long-term strategic outlook. This challenging task was exactly what the Maoist network in the PRD had accomplished. The Maoist activists were able to connect their immediate organising contexts with a long-term vision of a working-class revolution, however vaguely it was defined, and develop a sense of how the former could lead to the latter. A long-term strategy, despite its flaws, was formulated in a context in which almost no strategic thinking felt possible-and, all the more impressively, this strategy was implemented on the ground.

In order to operate, the many layers which this strategy involved-recruiting college graduates, identifying factories to send activists 
to, agitating for collective action, educating and retaining cadres of working-class origins, etc. - had to be extremely well coordinated. Any breakdown or disconnect between these layers could undermine the entire project. The functioning of this model over more than a decade and the progress it was able to make on these various fronts speak volumes to the organisational acumen of the activists. The problem of coordination was made all the more challenging because, for security reasons, many activists on the ground did not know what the others were doing. Therefore, the internal coordination heavily depended on several central nodes in the network. This, however, also meant the decision-making structure within the network was largely top-down.

In developing and implementing this strategy, the Maoist activists drew heavily upon Marxist classics, especially Lenin's What Is to Be Done (1961). In trying to develop a longterm revolutionary strategy for the Chinese labour movement, the activists attempted to adapt Lenin's insight to a political context that looked very different from the one in which Lenin was situated. As understood by these activists, Lenin provided a crucial way to think about the relationship between revolutionary politics and concrete workingclass struggles. Particularly important was the notion that a vanguard party should provide political leadership to the workers' movement, so as to make sure the latter would not remain confined within reformist tendencies posing no fundamental challenge to the status quo. In this framework, the party should lead the working class, but also remain organisationally distinct from it; the party's political leadership would be primarily realised by developing the most militant and politically conscious workers into revolutionary cadres of the party, who would then lead and agitate other workers. Translating this insight into praxis in a vastly different context required both a great deal of creativity and an engaged analysis of the peculiarities of Chinese labour. Leftist scholars and activists around the globe have long talked about connecting theory to praxis, but serious attempts at it in actual organising have been rare. For this reason, the sincere efforts made by these Maoists to apply classical Marxist insight to on-the-ground organising should serve as an inspiration.

It should also be noted that this strategy was implemented in the presence of a dauntingly repressive state. Similar to what Lenin had envisioned in Tsarist Russia, the organising model embraced by the Maoists in the PRD had to combine some open activity with other, secretive operations. Several layers of the model necessarily remained underground, as did the self-proclaimed long-term revolutionary goal to which this model was supposed to lead. This careful combination of open and underground work posed even more exacting demands on the activists' organisational skills. Nevertheless, they proved themselves to be up to the task.

\section{Lasting Challenges}

It is somewhat ironic that this labour organising strategy seems weakest when it comes to the actual process and art of organising workers-how to have organising conversations with workers, how to build a team of worker leaders on the shopfloor, how to cultivate trust among workers, how to move apathetic and fearful workers towards collective action, etc. Informants who had been part of this activist network reported receiving no training on the nuts and bolts of actual organising-including things as basic as how to approach and talk to fellow coworkers-before being sent into factories. As inexperienced organisers, they operated without guidance on what exactly to do in the factories and had to figure things out on their own. This, in part, explains the high attrition rate among activists who were college graduates. Similarly, relatively little effort was made to develop the newly recruited workersturned-activists into leaders on the shopfloor who possessed the confidence and skills necessary to move coworkers to action, though they received extensive political education 
on Maoist ideology. The lack of systematic accumulation and sharing of knowledge on the concrete skills of labour organising stands in sharp contrast to the extensive knowledge and materials the network developed regarding how to build support bases in universities and recruit college students. This is not to say none of the Maoist activists was a good labour organiser-some were. What was missing, however, was an organisational emphasis on developing good labour organisers.

Therefore, the self-identity of these Maoist activists in the PRD seemed to be that of revolutionary cadre, rather than labour organiser. Faced with a fragmented and sporadic labour movement, this activist network did not seek to build a slate of worker leaders organically embedded in their respective workplaces, who could then be connected to each other in some sort of relatively durable network; this would be one possible way to overcome the fragmentation of the Chinese labour movement. Instead, the Maoist activists sought to give coherence to a fragmented labour movement through a quasi-party political formation expected to not only grow in size but also propagate a Maoist revolutionary politics among the working class; the priority, therefore, was to build the party, rather than the organisational capacity of workers. The problem of this strategy was that this vanguard party could easily become detached from the broader working-class base, because of the lack of organic links with worker leaders.

Part of the problem here seems to originate from the very Leninst model these activists attempted to adapt. In this model, a conceptual and organisational distinction is made between the revolutionary vanguard party and the broader working class-the former is to lead and set the political agenda, whereas the latter is supposed to follow the former's leadership in a rather passive manner. The emphasis was not so much on building the necessary organisational capacity for workers to take massive action as on making sure workers' struggle unfolds in the correct political direction, under the guidance of revolutionary theory. In other words, the role of the party is supposed to be political, not organisational. The Maoist activist network inherited this conception in seeing that their task was fundamentally to recruit workers to revolutionary politics, and organising on the shopfloor was meaningful only insofar as it served this fundamental goal. They were not concerned with strengthening the self-capacity and collective militancy of workers per se. In fact, for the Maoist activists such capacity could be threatening, as the party would then find it much more difficult to control the political direction of workers' struggle.

A crucial contextual difference matters here. When Lenin wrote What Is to Be Done, the Russian labour movement had already gone a long way towards overcoming fragmentation by developing cross-industry, cross-region, and organisationally anchored momentum that was capable of sustaining a militant collective tradition. Therefore, the burning question became what kind of politics this labour movement should espouse. However, in contemporary China, where the labour movement suffers from the very lack of such momentum, the fundamental question of 'how to organise' should be addressed first. By sidelining this question, the Maoist activist network in the PRD failed to provide a workable path to overcome the fragmented and sporadic nature of the contemporary labour movement in China, however admirable their attempt was. Any future endeavours to overcome this challenge, I would argue, will have to put the question of organising front and centre. 
This text is taken from Made in China Journal: Volume 5, Issue 2, 2020 , edited by Ivan Franceschini and Nicholas Loubere, published 2020 by ANU Press, The Australian National University, Canberra, Australia.

doi.org/10.22459/MIC.05.02.2020.07 